\title{
Review: The Mediterranean Region
}

Source: The Geographical Journal, Vol. 24, No. 3 (Sep., 1904), p. 343

Published by: geographicalj

Stable URL: http://www.jstor.org/stable/1776594

Accessed: 27-06-2016 03:44 UTC

Your use of the JSTOR archive indicates your acceptance of the Terms \& Conditions of Use, available at

http://about.jstor.org/terms

JSTOR is a not-for-profit service that helps scholars, researchers, and students discover, use, and build upon a wide range of content in a trusted digital archive. We use information technology and tools to increase productivity and facilitate new forms of scholarship. For more information about JSTOR, please contact support@jstor.org.

The Royal Geographical Society (with the Institute of British Geographers), Wiley are collaborating with JSTOR to digitize, preserve and extend access to The Geographical Journal 


\title{
ANTHROPOGEOGRAPHY AND HISTORICAL GEOGRAPHY.
}

\author{
The Mediterranean Region.
}

'Das Mittelmeergebiet-Seine geographische und kulturelle Eigenart.' By A. Philippson. Pp. vi., 266. Illustrations and Maps. Leipzig: Teubner. 1904.

A well-known writer on the physical characteristics of the Greek peninsula makes herein a useful contribution to regional geography by treating the Mediterranean with its islands and coasts as a whole. The frontiers of his Mittelmeergebiet are, perhaps, somewhat vaguely drawn; for by no means does he take account of all the hydrographic basin of the Middle Sea, nor even of the orographic limits which he himself prescribes. For instance, neither the Alps nor the main chains of the Balkans, though assumed to bound the region, are reckoned as part of it; and this being so, it is difficult to see why the Atlas, and the internal plateau of Asia Minor, should, nevertheless, come into the author's purview. If the extent of hinterland to be included is somewhat arbitrary, it is, however, not less useful to have a comprehensive consideration of the sea itself with its shores. Dr. Philippson finds a geological unity in the region by regarding it all as a "Bruchzone," included within one volcanic area, which may be distinguished into a western and an eastern sub-area ; and as characterized in great part by a common earth-movement, viz. subsidence. Evidence that coastal movement on a large scale in certain parts of the region did not cease with the post-Pliocene epoch, but has continued in historical times, and is probably going on still, accumulates fast. We bave had before us recently Mr. Günther's observations upon the Neapolitan seaboard; the archæologists have been demonstrating still more lately the subsidence of the Nile delta in post-Roman times; and we have ourselves observed indubitable evidence of the same movement on the Cyrenaic shore.

Dr. Philippson classifies the borders of his sea into Schwemmlands-Kuste, Erosions-Kuste, and Ingressions-Kuste. A better classification might be dual, the true distinction being between the first and third. "Erosions Kuste" rosults from a secondary process, which modifies coasts formed primarily under one or two other of the remaining heads. But, at any rate, Dr. Philippson's classification serves to distinguish obvious varieties. A more serious objection might be found in the general unevenness of treatment, noticeable in this book. At least twice as much space, attention, and detail are devoted to the eastern Mediterranean as to the western, doubtless because the author has much more intimate personal acquaintance with the former area. The Spanish, French, Italian, and African coasts are surveyed very cursorily, and the treatment only becomes satisfactory when the Adriatic and the Egean are reached. Further, it is perhaps inevitable that such a general treatise as this should err on the side of generality. Certain distinctions of climate and life-distribution are too sweeping. For instance, central Asia Minor is neither so rainless nor so thinly populated as it is described in Dr. Philippson's text, or represented in his charts. The truth is that we have not yet enough data for several of the Mediterranean lands to allow of their being classified on broad lines with that hard systematic precision dear to German science.

With this warning, however, we can heartily recommend Dr. Philippson's book to those who wish to study or to teach the geographical conditions of the Mediterranean lands in their bearing on a long and intricate history. As is light and proper, the author always keeps the historical records in view, and uses them where possible, as, for example, in discussing the question of recent climatic change in the eastern basin. 